\title{
Nocardia jinanensis sp. nov., an amicoumacin B-producing actinomycete
}

\author{
Wei Sun, ${ }^{1}$ Yue-Oin Zhang, ${ }^{1}$ Ying Huang, ${ }^{2}$ Yu-Qin Zhang, \\ Zhao-Yong Yang ${ }^{1}$ and Zhi-Heng Liu ${ }^{2}$
}

\author{
Correspondence \\ Yue-Qin Zhang \\ zyq_0525@yahoo.com.cn \\ Ying Huang \\ huangy@im.ac.cn
}

\author{
${ }^{1}$ The National Key Laboratory for Screening New Microbial Drugs, Institute of Medicinal \\ Biotechnology, Chinese Academy of Medical Sciences, Beijing 100050, PR China \\ ${ }^{2}$ State Key Laboratory of Microbial Resources, Institute of Microbiology, Chinese Academy of \\ Sciences, Beijing 100101, PR China
}

\begin{abstract}
A novel actinomycete, strain $04-5195^{\top}$, that produces amicoumacin B, which targets bone morphogenetic protein-2, was isolated from a soil sample collected in Jinan, Shandong Province, China. Strain $04-5195^{\top}$ had morphological, biochemical, physiological and chemotaxonomic properties that were consistent with its classification in the genus Nocardia and it formed a phyletic line in the Nocardia 16S rRNA gene tree. It was evident from the phylogenetic data that strain $04-5195^{\top}$ was most closely associated with Nocardia speluncae N2-11 ${ }^{\top}$. However, the two organisms were distinguishable from one another using DNA-DNA relatedness and phenotypic data. The isolate was readily differentiated from other related Nocardia strains by a set of phenotypic properties and by its phylogenetic position. Therefore, it is proposed that the isolate represents a novel species in the genus Nocardia, Nocardia jinanensis sp. nov.; the type strain is $04-5195^{\top}\left(=\right.$ CGMCC $\left.4.3508^{\top}=\mathrm{DSM} 45048^{\top}\right)$.
\end{abstract}

The genus Nocardia was proposed by Trevisan (1889) with Nocardia farcinica as the original type species (the type species is now Nocardia asteroides). The genus belongs to the mycolic-acid-containing group of actinomycetes, members of which form extensively branched mycelia and substrate hyphae that fragment into rod-shaped, nonmotile elements (Goodfellow \& Lechevalier, 1989). The application of chemotaxonomic, numerical phenetic and molecular systematic methods has led to improved classification of members of the genus Nocardia (Goodfellow, 1998; Goodfellow et al., 1999). At the time of writing, the genus contained 71 species with validly published names. Many Nocardia species have been shown to be agents of human disease, such as $N$. asteroides, $N$. farcinica and Nocardia nova (Schaal \& Lee, 1992; Wallace et al., 1991), although it has also been shown that some species produce secondary metabolites of potential industrial value (Isik et al., 1999; Kinoshita et al., 2001), e.g. Nocardia uniformis, which can produce nocardicin. In the course of screening micro-organisms for new anti-osteo-

Abbreviation: BMP-2, bone morphogenetic protein-2.

The GenBank/EMBL/DDBJ accession number for the 16S rRNA gene sequence of strain $04-5195^{\top}$ is DQ462650.

A scanning electron micrograph of cells of strain $04-5195^{\top}$, an extended 16S rRNA gene sequence-based neighbour-joining tree and a comparison between the cultural characteristics of strain $04-5195^{\top}$ and $N$. speluncae DSM $45078^{\top}$ are available as supplementary material with the online version of this paper. porosis agents targeting bone morphogenetic protein-2 (BMP-2), an active compound (5195A) with the potential to increase expression of the BMP-2 gene was found in fermentation broth of a nocardioform actinomycete, strain $04-5195^{\mathrm{T}}$, that had been isolated from soil. The compound 5195A was identified as amicoumacin B (Yang et al., 2007), which has been reported previously to be produced by Bacillus pumilus (Itoh et al., 1982). A polyphasic taxonomic investigation based on genotypic and phenotypic characteristics revealed that isolate $04-5195^{\mathrm{T}}$ represents a novel species of the genus Nocardia.

Strain $04-5195^{\mathrm{T}}$ was isolated on a modified Sauton's agar plate (Mordarska et al., 1972) that had been incubated at $28{ }^{\circ} \mathrm{C}$ for 2 weeks following inoculation with a suspension of a soil sample collected from Jinan, Shandong Province, China. The isolate was maintained on yeast extract-malt extract agar (ISP 2; Shirling \& Gottlieb, 1966) slopes at $4{ }^{\circ} \mathrm{C}$ and as glycerol suspensions $(20 \%, \mathrm{v} / \mathrm{v})$ at $-20{ }^{\circ} \mathrm{C}$. All cultures were incubated at $28{ }^{\circ} \mathrm{C}$ unless otherwise indicated. Biomass for chemotaxonomic and molecular genetic studies was prepared as described previously (Sun et al., 2007).

The colonial properties of the isolate were observed on ISP 2 agar plates that had been incubated for 8 days. Morphological properties were detected following growth on ISP 2 plates and examined by using light microscopy (Axioskop 20; Zeiss) and scanning electron microscopy (Quanta; FEI). Well-established methods were used to determine a range of phenotypic properties (Goodfellow, 
1971; Williams et al., 1983). Acid production from carbohydrates was determined using media and methods described by Gordon et al. (1974) and the utilization of sole carbon sources was investigated according to Gordon \& Mihm (1957). $\mathrm{pH}$, temperature and $\mathrm{NaCl}$ tolerances were determined on ISP 2 agar plates incubated for up to 14 days. Established TLC procedures were used to determine diagnostic diaminopimelic acid isomers (Hasegawa et al., 1983), whole-cell sugar composition (Lechevalier \& Lechevalier, 1980) and polar lipids (Minnikin et al., 1984). Menaquinones were extracted and estimated using the methods of Collins (1985). The acid methanolysis procedure was used for extraction and analysis of mycolic acids (Minnikin et al., 1975). Fatty acids were extracted, methylated and estimated by GC using the standard Sherlock MIDI (Microbial Identification) system (Sasser, 1990; Kämpfer \& Kroppenstedt, 1996).

Chromosomal DNA was extracted from biomass of strain 04$5195^{\mathrm{T}}$ grown in modified Sauton's broth for 5 days at $28{ }^{\circ} \mathrm{C}$ and purified following the method of Rainey et al. (1996). The purified PCR product was sequenced according to the method of $\mathrm{Gu}$ et al. (2006). The DNA G+C content was determined using the thermal denaturation method (Marmur \& Doty, 1962) with Escherichia coli K-12 as a control. Levels of DNA-DNA relatedness between strain $04-5195^{\mathrm{T}}$ and related type strains were determined using the fluorometric microplate method of Ezaki et al. (1989). Hybridization experiments were carried out under stringent conditions in $50 \%$ formamide at $50{ }^{\circ} \mathrm{C}$. Fluorescence intensities were measured using a FLUOstar OPTIMA microplate reader (BMG LABTECH) at wavelengths of $360 \mathrm{~nm}$ for excitation and $460 \mathrm{~nm}$ for emission. Phylogenetic analysis was performed by first using the BLAST search program available at NCBI. The corresponding sequences of strains of representative species were then analysed using the software packages MEGA version 3.1 (Kumar et al., 2004) and PHYLIP version 3.5c (Felsenstein, 1993). Phylogenetic trees were constructed by the neighbourjoining (Saitou \& Nei, 1987), maximum-parsimony (Fitch, 1971), least-squares (Fitch \& Margoliash, 1967) and maximum-likelihood (Felsenstein, 1981) methods. Evolutionary distance matrices were generated according to the method of Kimura (1980). Bootstrap values were determined based on 1000 replications.

The phenotypic properties of strain $04-5195^{\mathrm{T}}$ were consistent with its assignment to the genus Nocardia (Goodfellow, 1998; Goodfellow et al., 1999). The organism was an aerobic, Gram-positive, slightly acid-alcohol-fast actinomycete. It developed well on a series of media including ISP 2, 4 and 5 agars (Shirling \& Gottlieb, 1966) and yeast extract-starch agar (DSMZ medium 1027); it showed moderate growth on ISP 6 agar (Shirling \& Gottlieb, 1966), Czapek-Dox agar (DSMZ medium 130) and modified Bennett's agar (Jones, 1949), but grew poorly on ISP 7 agar (Shirling \& Gottlieb, 1966) (see Supplementary Table S1, available in IJSEM Online). The substrate mycelium branched extensively and fragmented into non-motile, rod-shaped elements (see Supplementary Fig. S1).
The isolate contained mycolic acids. Whole-cell hydrolysates contained meso-diaminopimelic acid, arabinose and galactose (wall chemotype IV sensu Lechevalier \& Lechevalier, 1970). The polar phospholipids were phosphatidylethanolamine, phosphatidylinositol, phosphatidylinositol mannosides and minor amounts of phospholipids of unknown structure containing glucosamine (phospholipid type II sensu Lechevalier et al., 1977). The predominant menaquinone was MK-8 $\left(\mathrm{H}_{4}, \omega\right.$-cycl. $)$. The major cellular fatty acids were $\mathrm{C}_{16: 0}(28.5 \%), \mathrm{C}_{18: 0}(8.3 \%)$, $\mathrm{C}_{16: 1} \omega 7 c \quad(5.7 \%)$, iso- $\mathrm{C}_{15: 0} \quad 2-\mathrm{OH} \quad(5.8 \%), \mathrm{C}_{18: 1} \omega 9 c$ $(29.7 \%)$ and 10-methyl $\mathrm{C}_{18: 0}(10.9 \%)$.

An NCBI database search demonstrated that strain $04-5195^{\mathrm{T}}$ belonged to the genus Nocardia. 16S rRNA gene sequence similarities between strain $04-5195^{\mathrm{T}}$ and the closely related type strains Nocardia speluncae N2-11 ${ }^{\mathrm{T}}$, N. carnea DSM $43397^{\mathrm{T}}, N$. flavorosea JCM $3332^{\mathrm{T}}$, N. testacea JCM $12235^{\mathrm{T}}$ and N. sienata IFM $10088^{\mathrm{T}}$ were $99.0 \%$ (14 nt differences at 1397 sites), $98.2 \%$ (25/1404), $97.8 \%$ (31/1406), $97.7 \%$ (33/ $1406)$ and $97.8 \%(31 / 1402)$, respectively. It is clear from the phylogenetic analysis that strain $04-5195^{\mathrm{T}}$ forms a distinct phyletic line with $N$. speluncae $\mathrm{N} 2-11^{\mathrm{T}}$ in the Nocardia $16 \mathrm{~S}$ rRNA gene tree (Fig. 1; see also Supplementary Fig. S2). This line was supported by all four tree-making algorithms and by a $100 \%$ bootstrap value. Moreover, the four tree-making algorithms and the high bootstrap value supported the position of the strain $04-5195^{\mathrm{T}} / N$. speluncae $\mathrm{N} 2-11^{\mathrm{T}}$ phyletic line in the same clade as the other four related type strains above. The shortest phylogenetic distance (0.008) was observed between strain $04-5195^{\mathrm{T}}$ and N. speluncae N2$11^{\mathrm{T}}$. DNA-DNA hybridization was conducted between strain $04-5195^{\mathrm{T}}$ and $N$. speluncae DSM 45078 ${ }^{\mathrm{T}}$; DNADNA relatedness values between these two strains were $22.5 \pm 2.1 \%$, which is well below the $70 \%$ cut-off point generally recognized for genomic species (Wayne et al., 1987). A number of phenotypic properties (Table 1) also separated strain $04-5195^{\mathrm{T}}$ from the type strains of the most closely related species.

The genotypic and phenotypic data indicate that strain 04$5195^{\mathrm{T}}$ merits recognition as a representative of a novel species of Nocardia. It is therefore proposed that the isolate be classified in the genus Nocardia as the type strain of Nocardia jinanensis sp. nov.

\section{Description of Nocardia jinanensis sp. nov.}

Nocardia jinanensis (ji.nan.en'sis. N.L. fem. adj. jinanensis pertaining to Jinan, the capital city of Shandong Province, China, soil of which was the source of the type strain).

Aerobic, Gram-positive, catalase-positive, partially acidalcohol-fast, non-motile actinomycete that forms branched substrate mycelium that fragments in situ into irregular rodshaped elements. White to yellow substrate hyphae that bear sparse to abundant, white to yellowish aerial hyphae are formed on a number of agar media. Diffusible pigments are not produced. Aesculin is hydrolysed. Nitrate is not reduced to nitrite. Amylase and gelatinase are not produced. No 


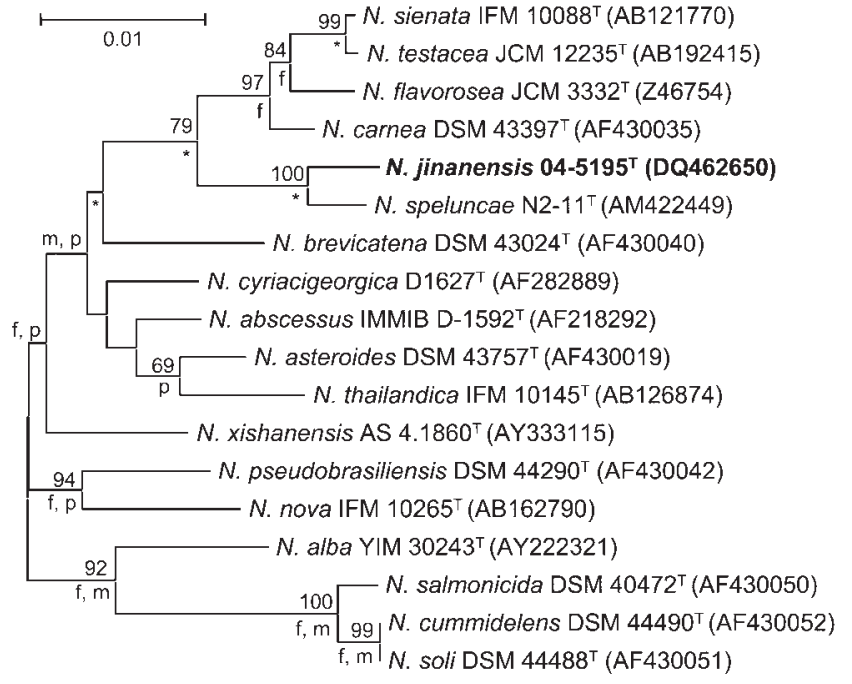

Fig. 1. Neighbour-joining tree (Saitou \& Nei, 1987) derived from aligned 16S rRNA gene sequences showing the position of strain $04-5195^{\top}$ among its nearest phylogenetic neighbours. Branches that were also recovered using the least-squares (Fitch \& Margoliash, 1967), maximum-parsimony (Fitch, 1971) and maximum-likelihood (Felsenstein, 1981) methods are indicated by the letters $f, p$ and $m$, respectively; asterisks indicate branches that were recovered using all three methods. Numbers at nodes indicate levels of bootstrap support (\%) based on a neighbourjoining analysis of 1000 resampled datasets; only values above $50 \%$ are indicated. Bar, 0.01 substitutions per nucleotide position. An extended tree is available as Supplementary Fig. S2. antibiosis is observed against strains of Bacillus subtilis, Candida albicans, Escherichia coli, Klebsiella pneumoniae, Mycobacterium smegmatis, Pseudomonas aeruginosa or Staphylococcus epidermidis. Grows in the presence of $3 \%$ $\mathrm{NaCl}$, but not in $5-10 \% \mathrm{NaCl}$. Acid is formed from Dfructose, D-galactose, mannitol, melezitose, raffinose, Dribose and salicin, but not from $\mathrm{D}$-arabinose, inositol, inulin, D-mannose, L-rhamnose or D-xylose. Dextrin, D-galactose, Dglucose, D-mannose and trehalose are utilized (all at $1 \%$, $\mathrm{w} / \mathrm{v})$, but $\mathrm{L}$-cysteine $(0.1 \%, \mathrm{w} / \mathrm{v})$, D-ribose $(1 \%, \mathrm{w} / \mathrm{v})$, sodium citrate $(0.1 \%, \mathrm{w} / \mathrm{v})$ and $\mathrm{D}$-xylose are not. Negative for decomposition of elastin $(0.3 \%$, w/v) and Tween 60 . Growth occurs at an initial $\mathrm{pH}$ of $5.5-10.5$ and between 15 and $37{ }^{\circ} \mathrm{C}$, but not at $\mathrm{pH} 3.5, \mathrm{pH} 4.5$ or $45^{\circ} \mathrm{C}$. Sensitive to filter-paper discs soaked in tobramycin $\left(10 \mu \mathrm{g} \mathrm{ml}^{-1}\right)$ and kanamycin $\left(30 \mu \mathrm{g} \mathrm{ml}^{-1}\right)$. Additional phenotypic properties are shown in Table 1 . The predominant cellular fatty acids are $\mathrm{C}_{18: 1} \omega 9 c$, $\mathrm{C}_{16: 0}$ and 10-methyl $\mathrm{C}_{18: 0}$. The species description is based on a single strain, which therefore serves as the type strain.

The type strain is $04-5195^{\mathrm{T}}$ (=CGMCC $4.3508^{\mathrm{T}}=\mathrm{DSM}$ $45048^{\mathrm{T}}$ ), isolated from a soil sample collected from Jinan city, Shandong Province, northern China. The DNA G + C content of the type strain is $65.0 \mathrm{~mol} \%$.

\section{Acknowledgements}

This research was supported by the National Facilities and Information Infrastructure for Science and Technology (grant no. 2005DKA21203) and the Natural Science Foundation of China (grant no. 30770002).

Table 1. Phenotypic properties that distinguish strain $04-5195^{\top}$ from type strains of related Nocardia species

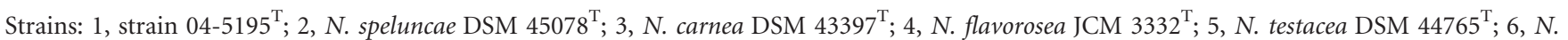
sienata DSM $44766^{\mathrm{T}}$. Data are from this study. + , Positive; - , negative; $\mathrm{w}$, weakly positive. All strains are negative for decomposition of adenine $(0.4 \%, w / v)$, guanine $(0.4 \%, w / v)$, hypoxanthine $(0.4 \%, w / v)$, tyrosine $(0.5 \%$, w/v), xanthine $(0.4 \% \mathrm{w} / \mathrm{v})$ and Tweens 20,40 and 80 .

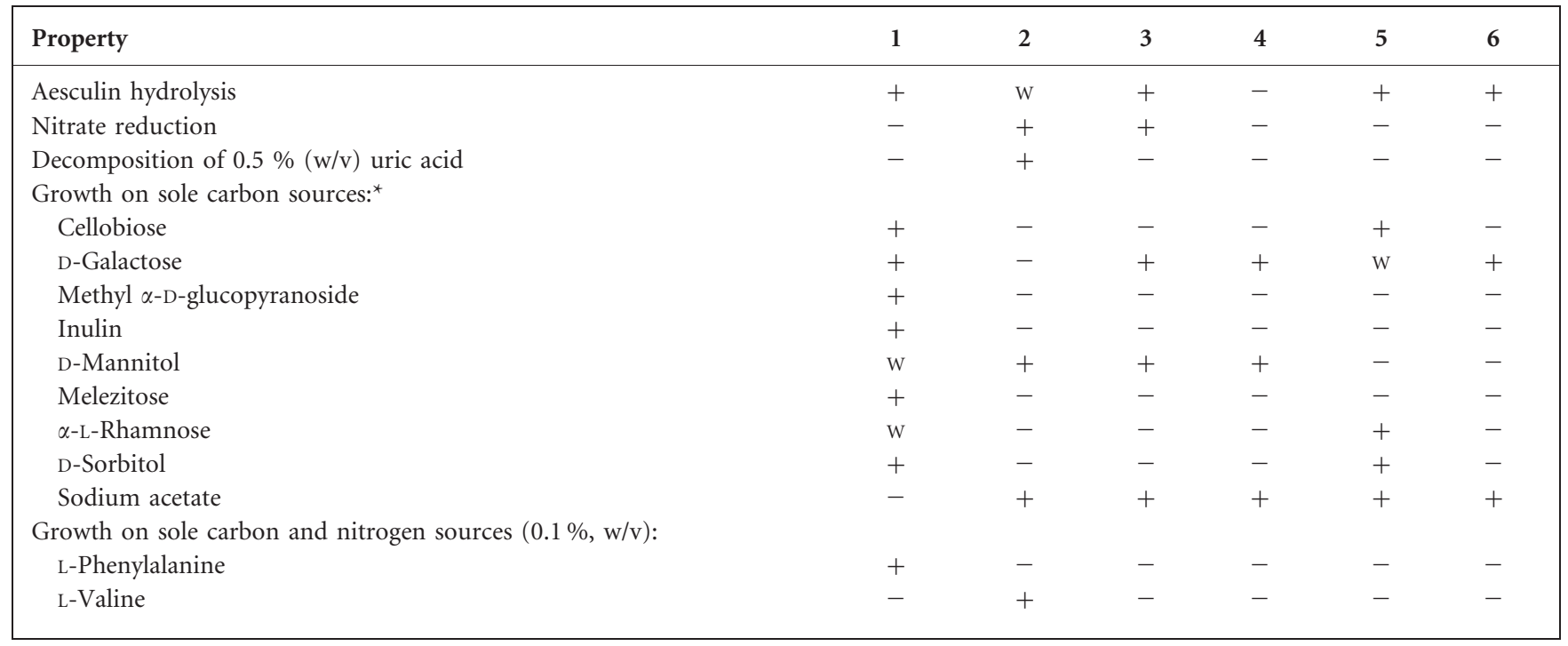

${ }^{\star}$ All at $1.0 \%(\mathrm{w} / \mathrm{v})$ apart from sodium acetate $(0.1 \%, \mathrm{w} / \mathrm{v})$. 


\section{References}

Collins, M. D. (1985). Isoprenoid quinone analysis in classification and identification. In Chemical Methods in Bacterial Systematics, pp. 267-287. Edited by M. Goodfellow \& D. E. Minnikin. London: Academic Press.

Ezaki, T., Hashimoto, Y. \& Yabuuchi, E. (1989). Fluorometric deoxyribonucleic acid-deoxyribonucleic acid hybridization in microdilution wells as an alternative to membrane filter hybridization in which radioisotopes are used to determine genetic relatedness among bacterial strains. Int J Syst Bacteriol 39, 224-229.

Felsenstein, J. (1981). Evolutionary trees from DNA sequences: a maximum likelihood approach. J Mol Evol 17, 368-376.

Felsenstein, J. (1993). PHYLIP (phylogeny inference package), version 3.5c. Distributed by the author. Department of Genome Sciences, University of Washington, Seattle, USA.

Fitch, W. M. (1971). Toward defining the course of evolution: minimum change for a specific tree topology. Syst Zool 20, 406-416.

Fitch, W. M. \& Margoliash, E. (1967). Construction of phylogenetic trees. Science 155, 279-284.

Goodfellow, M. (1971). Numerical taxonomy of some nocardioform bacteria. J Gen Microbiol 69, 33-80.

Goodfellow, M. (1998). Nocardia and related genera. In Topley and Wilson's Microbiology and Microbial Infections, 9th edn, vol. 2, Systematic Bacteriology, pp. 463-489. Edited by A. Balows \& B. I. Duerden. London: Arnold.

Goodfellow, M. \& Lechevalier, M. P. (1989). Genus Nocardia Trevisan $1889,9^{\mathrm{AL}}$. In Bergey's Manual of Systematic Bacteriology, vol. 4, pp. 2350-2361. Edited by S. T. Williams, M. E. Sharpe \& J. G. Holt. Baltimore: Williams \& Wilkins.

Goodfellow, M., Isik, K. \& Yates, E. (1999). Actinomycete systematics: an unfinished synthesis. Nova Acta Leopold NF80, 47-82.

Gordon, R. E. \& Mihm, J. M. (1957). A comparative study of some strains received as nocardiae. J Bacteriol 73, 15-27.

Gordon, R. E., Barnett, D. A., Handerhan, J. E. \& Pang, C. H.-N. (1974). Nocardia coeliaca, Nocardia autotrophica, and the nocardin strain. Int J Syst Bacteriol 24, 54-63.

Gu, Q., Luo, H., Zheng, W., Liu, Z. \& Huang, Y. (2006). Pseudonocardia oroxyli sp. nov., a novel actinomycete isolated from surface-sterilized Oroxylum indicum root. Int J Syst Evol Microbiol 56, 2193-2197.

Hasegawa, T., Takizawa, M. \& Tanida, S. (1983). A rapid analysis for chemical grouping of aerobic actinomycetes. J Gen Appl Microbiol 29, 319-322.

Isik, K., Chun, J., Hah, Y. C. \& Goodfellow, M. (1999). Nocardia uniformis nom. rev. Int J Syst Bacteriol 49, 1227-1230.

Itoh, J., Omoto, S., Nishizawa, N., Kodama, Y. \& Inouye, S. (1982). Chemical structures of amicoumacins produced by Bacillus pumilus. Agric Biol Chem 46, 2659-2665.

Jones, K. L. (1949). Fresh isolates of actinomycetes in which the presence of sporogenous aerial mycelia is a fluctuating characteristic. J Bacteriol 57, 141-145.

Kämpfer, P. \& Kroppenstedt, R. M. (1996). Numerical analysis of fatty acid patterns of coryneform bacteria and related taxa. Can J Microbiol 42, 989-1005.

Kimura, M. (1980). A simple method for estimating evolutionary rates of base substitutions through comparative studies of nucleotide sequences. J Mol Evol 16, 111-120.

Kinoshita, N., Homma, Y., Igarashi, M., Ikeno, S., Hori, M. \& Hamada, M. (2001). Nocardia vinacea sp. nov. Actinomycetologica 15, 1-5.
Kumar, S., Tamura, K. \& Nei, M. (2004). MEGA3: integrated software for molecular evolutionary genetics analysis and sequence alignment. Brief Bioinform 5, 150-163.

Lechevalier, M. P. \& Lechevalier, H. A. (1970). Chemical composition as a criterion in the classification of aerobic actinomycetes. Int J Syst Bacteriol 20, 435-443.

Lechevalier, H. A. \& Lechevalier, M. P. (1980). The chemotaxonomy of actinomycetes. In Actinomycete Taxonomy, Special Publication 6, pp. 227-291. Edited by A. Dietz \& D. W. Thayer. Arlington, VA: Society for Industrial Microbiology.

Lechevalier, M. P., De Bièvre, C. \& Lechevalier, H. A. (1977). Chemotaxonomy of aerobic actinomycetes: phospholipid composition. Biochem Syst Ecol 5, 249-260.

Marmur, J. \& Doty, P. (1962). Determination of the base composition of deoxyribonucleic acid from its thermal denaturation temperature. J Mol Biol 5, 109-118.

Minnikin, D. E., Alshamaony, L. \& Goodfellow, M. (1975). Differentiation of Mycobacterium, Nocardia, and related taxa by thin-layer chromatographic analysis of whole-organism methanolysates. J Gen Microbiol 88, 200-204.

Minnikin, D. E., O’Donnell, A. G., Goodfellow, M., Alderson, G., Athalye, M., Schaal, A. \& Parlett, J. H. (1984). An integrated procedure for the extraction of bacterial isoprenoid quinones and polar lipids. J Microbiol Methods 2, 233-241.

Mordarska, H., Mordarski, M. \& Goodfellow, M. (1972). Chemotaxonomic characters and classification of some nocardioform bacteria. J Gen Microbiol 71, 77-86.

Rainey, F. A., Ward-Rainey, N., Kroppenstedt, R. M. \& Stackebrandt, E. (1996). The genus Nocardiopsis represents a phylogenetically coherent taxon and a distinct actinomycete lineage: proposal of Nocardiopsaceae fam. nov. Int J Syst Bacteriol 46, 1088-1092.

Saitou, N. \& Nei, M. (1987). The neighbor-joining method: a new method for reconstructing phylogenetic trees. Mol Biol Evol 4, 406425.

Sasser, M. (1990). Identification of bacteria by gas chromatography of cellular fatty acids, MIDI Technical Note 101. Newark, DE: MIDI Inc.

Schaal, K. P. \& Lee, H. J. (1992). Actinomycete infections in humans - a review. Gene 115, 201-211.

Shirling, E. B. \& Gottlieb, D. (1966). Methods for characterization of Streptomyces species. Int J Syst Bacteriol 16, 313-340.

Sun, W., Huang, Y., Zhang, Y.-Q. \& Liu, Z.-H. (2007). Streptomyces emeiensis sp. nov., a novel streptomycete from soil in China. Int J Syst Evol Microbiol 57, 1635-1639.

Trevisan, V. (1889). I Generi e le Specie delle Batteriacee. Milan: Zanaboni \& Gabuzzi (in Italian).

Wallace, R. J.JrBrown, B. A., Tsukamura, M., Brown, J. M. \& Onyi, G. O. (1991). Clinical and laboratory features of Nocardia nova. J Clin Microbiol 29, 2407-2411.

Wayne, L. G., Brenner, D. J., Colwell, R. R., Grimont, P. A. D., Kandler, O., Krichevsky, M. I., Moore, L. H., Moore, W. E. C., Murray, R. G. E. \& other authors (1987). International Committee on Systematic Bacteriology. Report of the ad hoc committee on reconciliation of approaches to bacterial systematics. Int J Syst Bacteriol 37, 463-464.

Williams, S. T., Goodfellow, M., Alderson, G., Wellington, E. M. H., Sneath, P. H. A. \& Sackin, M. J. (1983). Numerical classification of Streptomyces and related genera. J Gen Microbiol 129, 1743-1813.

Yang, Z., Sun, W., Yang, J., Ding, Y., Si, S. \& Zhang, Y. (2007). Study of the effect of a production of Nocardia 04-5195 amicoumacin B on BMP-2 gene. Chin Pharm J 42, 268-271. 